\title{
Avaliação de conhecimentos de estudantes do ensino médio acerca da cadeia de sobrevivência em suporte básico de vida antes e após treinamento teórico-prático
}

\section{The evaluation of high school students' knowledge about basic life support before and after theoretical-practical training}

Louise Martins Nunes ${ }^{1}$. Marcelo Kervin Reis Frota ${ }^{1}$. Matheus Augusto Mesquita Fernandes ${ }^{1}$. Thainá Pompeu de Almeida ${ }^{1}$. Thaís Maria Lopes de Sousa ${ }^{1}$. Claudia Regina Fernandes ${ }^{1}$.

1 Universidade Federal do Ceará (UFC), Fortaleza, Ceará, Brasil.

\section{RESUMO}

Objetivos: Avaliar o conhecimento de estudantes de ensino médio acerca de suporte básico de vida (SBV). Método: Estudo realizado em escola pública, com estudantes de ensino médio. Foram seguidos os passos: 1) aplicação de um questionário, com o objetivo de averiguar os conhecimentos prévio dos alunos sobre o tema; 2) apresentação de uma conferência dialogada sobre a cadeia de sobrevivência em situações de parada cardiorrespiratória (PCR); 3) desenvolvimento de habilidades práticas com os estudantes de como atuar frente à uma situação de PCR, seguindo a cadeia de sobrevivência; 4) aplicação do mesmo questionário, com o objetivo de averiguar os conhecimentos dos alunos após o desenvolvimento da atividade. Resultados: A média de acertos quando se comparou o pré e pós-teste considerando perguntas referente à cadeia de sobrevivência, atendimento pré-hospitalar pelo SAMU, reanimação cardiopulmonar (RCP) e PCR apresentou diferença significativa (teste de wilcoxon $\mathrm{p}<0,001$ ). Conclusão: Houve significativa aquisição de conhecimentos teóricos por estudantes de ensino médio acerca da cadeia de sobrevivência em SBV após intervenção teórico-prática. Dessa forma, inferindo que estas ações de extensão universitária contribuem para educar a população, podendo resultar em diminuição da mortalidade em casos de PCR em ambiente extra-hospitalar.

Palavras-chave: Reanimação cardiopulmonar. Extensão comunitária. Educação médica. Parada cardiorrespiratória.

\section{ABSTRACT}

Object: Evaluate the knowledge of high school students about the links of the survival chain and the understanding of Basic Life Support (BLS). Method: Study conducted in a public school with high school students. The following steps were followed: 1) Application of a questionnaire, with the objective of ascertaining the students' previous knowledge on the subject; 2) Presentation of a dialogued conference on the survival chain in cardiac arrest situations; 3) Development of practical skills with students on how to act in a PCR situation, following the survival chain; 4) Application of the same questionnaire in order to ascertain students' knowledge after the development of the activity. Results: the average of correct answers when comparing the pre and post-test considering questions regarding the survival chain, prehospital care by SAMU, cardiopulmonary resuscitation and cardiac arrest showed a significant difference (Wilcoxon test $\mathrm{p}<0.001$ ). Conclusion: There was a significant acquisition of theoretical knowledge by high school students about the survival chain in Basic Life Support, after the theoretical and practical intervention, inferring that these university extension actions contribute to educating the population and may result in reduced mortality in cases of CRP in an out-of-hospital setting.

Keywords: Cardiopulmonary resuscitation. Community-institutional relations. Education, medical. Heart arrest.

Autor correspondente: Louise Martins Nunes, Rua Professor Costa Mendes, 1608, Bloco didático, Rodolfo Teófilo, Fortaleza, Ceará. CEP: 60430140. Telefone: +55 85 3366-8061. E-mail: louisemnunes@hotmail.com

Conflito de interesses: Não há qualquer conflito de interesses por parte de qualquer um dos autores.

Recebido em: 06 Jun 2020; Revisado em: 16 Out 2020; Aceito em: 12 Jan 2021. 


\section{INTRODUÇÃO}

No Brasil, estima-se que ocorram mais de 200 mil paradas cardiorrespiratórias anualmente, com a maioria dos casos ocorrendo fora do ambiente hospitalar, com baixa taxa de sobrevivência. Representando assim um grave problema de saúde pública. ${ }^{1}$

Diante de pacientes com sinais de parada cardiorrespiratória em ambiente extra-hospitalar, o seguimento sistematizado dos passos da cadeia de sobrevivência da American Heart Association (AHA) é: reconhecimento da parada, acionamento do serviço médico de emergência e início das manobras de reanimação cardiopulmonar - o que possibilita aumento de sobrevida por um atendimento efetivo. ${ }^{2}$ Nesse elo de assistência, o acionamento precoce do serviço médico de emergência, no Brasil denominado Serviço de Atendimento Móvel de Urgência (SAMU), representa etapa decisiva possibilitando melhor desfecho. ${ }^{3}$

Com o objetivo de otimizar o atendimento precoce às vítimas de diversas enfermidades, incluindo a parada cardiorrespiratória, políticas públicas de diversos países estruturaram serviços de atendimento móvel pré-hospitalar. ${ }^{4}$ No Brasil, o SAMU foi estabelecido a partir de um acordo bilateral assinado com a França, por iniciativa do Ministério da Saúde, no início da década de $1990 .{ }^{5}$ Embora já tenha se passado mais de três décadas, ainda há desconhecimento da população, ${ }^{6}$ inclusive estudantes de medicina, ${ }^{7}$ acerca de como esse serviço funciona, por qual número telefônico deve ser acionado e de como deve ser feito a comunicação efetiva na solicitação de socorro.

Alguns aspectos estão relacionados com a sobrevida dos pacientes acometidos por PCR, tais como: o tempo decorrido entre o início da deterioração clínica até o atendimento médico especializado, o início das manobras de suporte básico de vida (SBV) pela população leiga ${ }^{8}$ o conhecimento teórico dos socorristas, ${ }^{9}$ a qualidade das manobras de ressuscitação cardiopulmonar e os recursos disponíveis. ${ }^{10}$

Sabe-se que pacientes que recebem Reanimação Cardiopulmonar por pessoas próximas possuem taxa de sobrevivência cerca de 2-3 vezes maior do que aqueles pacientes que não recebem tais esforços. ${ }^{11}$ Contudo, as taxas de sobrevivência continuam sendo baixas, pois, mesmo após o retorno espontâneo da circulação, mais de $60 \%$ dos pacientes admitidos para cuidados hospitalares pós-parada morrem de complicações decorrentes da PCR inicial. ${ }^{12}$

Observa-se que são escassas as iniciativas com o intuito de promover treinamentos acerca de suporte básico de vida para a população leiga, apesar dos comprovados benefícios para os pacientes. ${ }^{13}$ Ressalta-se como exemplo de iniciativas nacionais, as atividades de treinamento teórico-prático realizadas por ligas acadêmicas de Medicina, as quais utilizam manequins e simuladores de desfibriladores externos automáticos (DEA), auxiliando na demonstração de um possível atendimento real para a população leiga. ${ }^{14}$ Reconhecese que as escolas constituem locais ideais para tais iniciativas, tendo em vista o número de adolescentes, a possibilidade de acompanhar a aquisição de conhecimentos teórico-práticos e o fato de eles serem potenciais testemunhas de uma parada cardiorrespiratória. ${ }^{15}$

A literatura diverge em relação à idade recomendada para o início da educação em Suporte Básico de Vida, levando em consideração, entre outros aspectos, o entendimento por parte dos estudantes sobre a importância do tema e a capacidade do adolescente de desenvolver performance capaz de resultar em compressão torácica eficiente. ${ }^{16}$

Diante da necessidade de expansão do conhecimento acerca do tema para a população em geral e entendendo que os jovens adolescentes podem ser agentes multiplicadores em sua comunidade, o objetivo do presente estudo foi avaliar o conhecimento de jovens estudantes de ensino médio acerca da cadeia de sobrevivência, que envolve o reconhecimento da PCR, o acionamento do SAMU e a compreensão sobre SBV, antes e após intervenção teórico-prática.

\section{MATERIAIS E MÉTODOS}

Foi realizado um estudo quantitativo, exploratório, descritivo, transversal, aprovado pelo CEP da Universidade Federal do Ceará CAAE: 02205418.0.0000.5054, número do parecer: 3.066.265, no qual foram avaliados 238 estudantes do segundo ano do ensino médio de uma escola pública da cidade de Fortaleza, capital do Estado do Ceará, localizada na região nordeste do Brasil.

Este estudo faz parte de um projeto de extensão da Liga de Emergência da Faculdade de Medicina da Universidade Federal (FAMED-UFC). A escola pública selecionada já tinha vínculo com a FAMED-UFC, através de projetos esportivos. Inicialmente, a direção da escola foi procurada pelos alunos da Liga e posteriormente foi apresentado o projeto de extensão à direção e aos professores. Após aceitação do projeto pela escola, iniciou-se o planejamento da ação. A gestão da escola indicou alunos do segundo ano do ensino médio como público alvo. Foram selecionadas duas sextas-feiras do mês de dezembro/2018, em horário de aula, para desenvolvimento da atividade, realizada nas próprias salas de aula. No total, foram abordadas sete turmas; quatro em uma primeira sexta, no turno da tarde, e três turmas na sexta seguinte. Ao todo, 12 alunos da Liga participaram como instrutores da atividade, dividindo-se em três membros por turma, sendo que em cada sala foi montado uma estação prática. Cada estação foi igualmente projetada com o objetivo de minimizar as barreiras de aprendizagem e de otimizar o desempenho da $\mathrm{RCP},{ }^{17}$ sendo composta por um manequim MiniAnne (Laerdal Medical, Stavanger, Noruega) e um Desfibrilador Externo Automático (DEA). A atividade teve duração total de 110 minutos por turma.

Inicialmente, foi explicado que o objetivo de aprendizagem estava relacionado à parada cardíaca, à cadeia de sobrevivência e ao suporte básico de vida (SBV). A atividade constava de 
quatro etapas: 1) aplicação de um questionário, denominado pré-teste, com o objetivo de averiguar os conhecimentos prévios dos alunos sobre o tema; 2) apresentação de uma conferência dialogada sobre a cadeia de sobrevivência em situações de parada cardiorrespiratória (PCR); 3) desenvolvimento de habilidades práticas com os estudantes de como atuar frente à uma situação de PCR, seguindo a cadeia de sobrevivência; 4) aplicação do mesmo questionário, agora denominado pós-teste com o objetivo de averiguar os conhecimentos dos alunos após o desenvolvimento da atividade.

O pré-teste foi programado para ser aplicado em 10 minutos, constava de 10 perguntas objetivas e diretas, sendo que três destas eram relacionadas à $\mathrm{PCR} / \mathrm{RCP}$ e sete eram relacionadas ao conhecimento sobre o atendimento préhospitalar (SAMU). O conteúdo do questionário foi validado através de entrevista cognitiva de cinco leigos para assegurar que cada pergunta era compreensível e as respostas não ambíguas. Cada questão tinha quatro quesitos plausíveis de resposta.

A conferência dialogada foi ministrada por acadêmicos de medicina integrantes da Liga de Emergência da FAMED-UFC, sob a supervisão de um professor, com duração de 45 minutos. Nessa conferência, foi abordado sobre a importância do SAMU, quando e como acionar este serviço, quais informações devem ser fornecidas e o malefício dos "trotes". Foram também temas de discussão: reconhecimento da vítima em PCR, realização efetiva das manobras de SBV (compressões torácicas) e uso do DEA, além do entendimento sobre a cadeia de sobrevivência.

Em seguida, os alunos participaram de uma prática simulada sobre a cadeia de sobrevivência, com duração de 45 minutos. A grande maioria dos estudantes participaram, alguns somente observaram. Nesta atividade, primeiramente, houve demonstração e posteriormente foi estabelecido que os alunos realizariam, sob supervisão e feedback imediato, as seguintes habilidades: 1) reconhecimento da PCR, 2) acionamento correto do SAMU, solicitando ambulância e desfibrilador, 3) compressões torácicas e 4) manuseio correto do DEA.

A última parte da atividade foi a aplicação do mesmo questionário realizado ao início, também com duração de 10 minutos, a fim de se avaliar a evolução do conhecimento dos alunos por meio de comparação entre o pré e o pós-teste.

Os dados foram categorizados e tabulados em planilha eletrônica no software Microsoft Excel $2016^{\circledR}$, e em seguida analisados no programa estatístico JAMOVI, cujos resultados foram apresentados em tabelas e gráficos. Para análise de associações estatísticas foi utilizado o teste de Wilcoxon. O objetivo destas análises foi encontrar diferenças estatísticas entre o número de acertos nas perguntas no momento do pré e do pós-teste.

Quanto às variáveis numéricas, os dados foram apresentados em mediana e percentis. Nas variáveis categóricas os dados foram expostos em frequência e taxa de prevalência de modo a investigar associações. Adotou-se um nível de significância de 5\%.

\section{RESULTADOS}

O número de alunos que participou da pesquisa foi 238 , todos cursando o segundo ano do ensino médio, sendo $51 \%$ do sexo feminino e $49 \%$ masculino (Tabela 1). A idade dos estudantes variou entre 15 e 19 anos, com uma média de 16,4 anos para ambos os grupos.

O Quadro 1 apresenta dados descritivos sobre o tipo de pergunta e o índice de acertos antes e após o treinamento teórico-prático.

Tabela 1. Dados demográficos dos estudantes participantes do estudo.

\begin{tabular}{ll}
\hline Sexo & Média de idades \\
\hline Feminino $124(51 \%)$ & 16,4 \\
Masculino $114(49 \%)$ & 16,4 \\
\hline
\end{tabular}

Quadro 1. Descrição das perguntas e respostas corretas e o índice de acertos antes e após a abordagem teórico-prática.

\begin{tabular}{|l|l|l|l|}
\hline $\begin{array}{l}\text { Tema da } \\
\text { pergunta }\end{array}$ & Perguntas & Acerto Pré-teste & Acerto Pós-teste \\
\hline PCR/RCP & $\begin{array}{l}\text { O que é uma parada cardiorrespiratória? } \\
\text { Resposta: é quando o coração não bate e os pulmões não funcionam. }\end{array}$ & $57,1 \%$ & $89 \%$ \\
\hline SAMU & $\begin{array}{l}\text { Qual o número do Serviço de Atendimento Móvel de Urgência (SAMU)? } \\
\text { Resposta: } 192 .\end{array}$ & $84 \%$ & $99,6 \%$ \\
\hline PCR/RCP & $\begin{array}{l}\text { O que é um desfibrilador? } \\
\text { Resposta: é uma máquina que aplica choques na vítima para tentar fazer o } \\
\text { coração bater novamente. }\end{array}$ & $93,7 \%$ & $98,7 \%$ \\
\hline
\end{tabular}

Continua. 
Conclusão.

Quadro 1. Descrição das perguntas e respostas corretas e o índice de acertos antes e após a abordagem teórico-prática.

\begin{tabular}{|c|c|c|c|}
\hline $\begin{array}{l}\text { Tema da } \\
\text { pergunta }\end{array}$ & Perguntas & Acerto Pré-teste & Acerto Pós-teste \\
\hline SAMU & $\begin{array}{l}\text { Você estava caminhando na Beira-Mar e se depara com uma pessoa } \\
\text { aparentemente inconsciente. Checa então se a cena está segura, confirmando } \\
\text { que ela está. Após isso, o que deve ser feito? } \\
\text { Resposta: aproximar-se e chamar pela vítima para verificar se ela de fato está } \\
\text { inconsciente. Se ela estiver, deve-se chamar o SAMU imediatamente e depois } \\
\text { checar se respira. }\end{array}$ & $75,2 \%$ & $94,5 \%$ \\
\hline $\mathrm{PCR} / \mathrm{RCP}$ & $\begin{array}{l}\text { Sobre as compressões torácicas assinale a alternativa correta: } \\
\text { Resposta: devem ser feitas em casos em que o coração não bate e a pessoa } \\
\text { não respira. }\end{array}$ & $59,2 \%$ & $82,3 \%$ \\
\hline SAMU & $\begin{array}{l}\text { Você se depara com uma Parada Cardiorrespiratória em uma via pública e } \\
\text { fica responsável por ligar para o SAMU. O que se deve falar durante a ligação } \\
\text { para a telefonista? } \\
\text { Resposta: deve-se fornecer o maior número de informações para a telefonista, } \\
\text { principalmente o nome de quem está ligando, número de telefone para contato, } \\
\text { endereço da ocorrência, estado da vítima, número de vítimas e capacidade de } \\
\text { prestar socorro. }\end{array}$ & $55 \%$ & $83,1 \%$ \\
\hline SAMU & $\begin{array}{l}\text { Acerca das ambulâncias do SAMU no Ceará, marque a resposta correta: } \\
\text { Resposta: apenas algumas ambulâncias do SAMU são compostas por médicos, } \\
\text { enfermeiros e motorista. }\end{array}$ & $29,4 \%$ & $86,9 \%$ \\
\hline SAMU & $\begin{array}{l}\text { Quais são os locais em que o SAMU pode atender? } \\
\text { Resposta: o SAMU pode atender em residências, vias públicas e locais de } \\
\text { trabalho. }\end{array}$ & $71,5 \%$ & $71,4 \%$ \\
\hline SAMU & $\begin{array}{l}\text { Em que situações podemos ligar para o SAMU pedindo ajuda? } \\
\text { Resposta: PCR, AVC, quedas com fraturas em idosos, pessoas com ferimento } \\
\text { por armas de fogo e por facadas. }\end{array}$ & $91,6 \%$ & $95,4 \%$ \\
\hline SAMU & $\begin{array}{l}\text { Sobre os tipos de ambulância do SAMU, marque a alternativa correta. } \\
\text { Resposta: existem dois tipos principais de ambulâncias no SAMU, a Unidade } \\
\text { de Saúde Básica e a Unidade de Saúde Avançada. }\end{array}$ & $58,8 \%$ & $89,9 \%$ \\
\hline
\end{tabular}

A média geral de acerto no grupo dos 238 alunos no pré-teste foi de $67,6 \%$, e no pós-teste de $89,1 \%$. Sendo observado diferença significativa entre estes resultados (teste Wilcoxon, $\mathrm{p}<0,001)$, como demonstra o Gráfico 1 .

Pôde-se observar que a pergunta com menor índice de acertos $(29,4 \%)$ foi aquela referente aos recursos humanos que estão presentes nas ambulâncias, em que a resposta correta sinalizava que apenas algumas ambulâncias do SAMU são compostas por médicos enfermeiros e motorista-socorrista, após a explanação o índice de acerto desta questão subiu para 86,9\%.

A pergunta com maior taxa de acertos no pré-teste foi sobre o conceito de desfibrilador (93,7\%), aumentando para $98,7 \%$ após a abordagem teórico-prática.
Quando se analisa apenas as perguntas referentes ao SAMU (Gráfico 2), observa-se que houve um aumento significativo no índice de acertos quando se compara o pré e pós-teste $(\mathrm{p}<$ 0,001).

O mesmo acontece quando se analisa o índice de acertos entre o pré e o pós-teste em relação às perguntas referentes a PCR/ RCP (Gráfico 3).

Aplicando-se o teste de Wilcoxon comparando os acertos no pré e pós-teste referente aos dois tópicos PCR/RCP e SAMU observou-se diferença significativa entre os dois momentos - demonstrado na Tabela 2, a partir dos valores de média, percentis 25 e 75 e com $\mathrm{p}<0,001$. 
Gráfico 1. Box plot de acertos no pré e pós-teste considerando o total de perguntas.

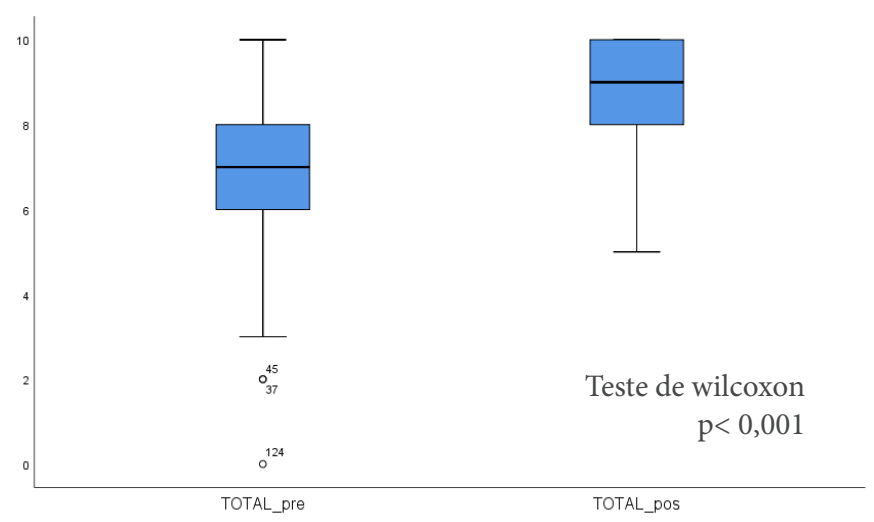

Gráfico 2. Média de acertos no pré e pós-teste considerando perguntas referente ao SAMU.

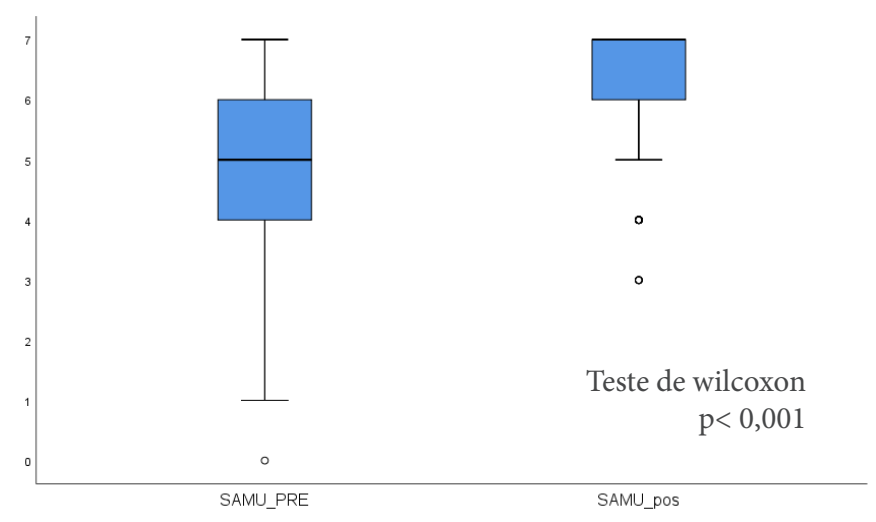

Gráfico 3. Média de acertos no pré e pós-teste considerando perguntas referente à $\mathrm{PCR} / \mathrm{RCP}$.

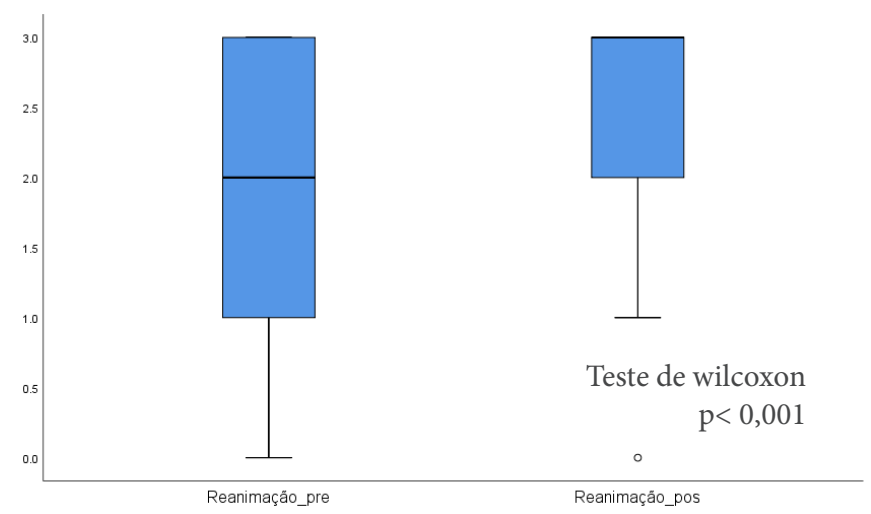

Tabela 2. Dados expressos em mediana (percentil 25 - percentil 75). a: estatística do teste de Wilcoxon.

\begin{tabular}{lcccc}
\hline & Pré & Pós & $\mathrm{z}^{\mathrm{a}}$ & $\mathrm{p}$ \\
\hline Samu & $5(4-6)$ & $7(6-7)$ & -11.245 & $<0.001$ \\
Reanimação & $2(1-3)$ & $3(2-3)$ & -8.665 & $<0.001$ \\
Total & $7(6-8)$ & $8(8-10)$ & -11.906 & $<0.001$ \\
\hline
\end{tabular}

\section{DISCUSSÃO}

Este estudo demonstra que estudantes de ensino médio possuíam conhecimentos gerais razoáveis sobre o tema cadeia de sobrevivência em situações de PCR em ambiente pré-hospitalar. Evidencia também que após a intervenção teórico-prática foi obtido incremento significativo nos conhecimentos. Observou-se que a maior carência de conhecimentos estava no elo acionamento serviço médico de emergência.

O conhecimento da população leiga acerca de PCR e da cadeia de reanimação é de extrema importância a fim de otimizar o tempo de chegada do serviço médico e de aumentar a sobrevida do paciente. ${ }^{8}$ É de conhecimento amplo que se a $\mathrm{RCP}$ for iniciada precocemente por pessoas próximas à vítima, antes da chegada do suporte avançado de vida (SAMU), a sobrevida pode aumentar em 200-300\% quando se compara ao atendimento iniciado apenas após a chegada de profissionais de saúde qualificados ao local. ${ }^{11}$ Contudo, a chegada desses profissionais precisa ser rápida. Para que isso aconteça, faz-se necessário o acionamento correto do SAMU.

Neste estudo foi demonstrado que os conhecimentos prévios dos alunos referente a PCR/RCP atingiu índice de acerto $>50 \%$. Considera-se esse número razoável, visto que muito provavelmente ainda não haviam sido expostos diretamente ao assunto. Acerca de conhecimentos sobre $\mathrm{SBV}$, tanto a população leiga ${ }^{13}$ quanto estudantes de ensino médio de escolas públicas e privadas ${ }^{1}$ possuem conhecimento escassos e precisam ser capacitados, sendo demonstrado que se pode produzir aprendizagem significativa após abordagem teórico-prática, ${ }^{16}$ conforme observado no presente estudo.

Interessante observar que, o conceito correto de desfibrilador foi apontado por $93,7 \%$ dos alunos. Imagina-se que programas de televisão e mídias digitais tenham contribuído para a aquisição prévia desses conhecimentos.

O SAMU foi adotado nacionalmente a partir de 2003, com elaboração de normas federais. ${ }^{18}$ É baseado no sistema francês, onde também há uma central de regulação gerenciada por médicos. Existem dois tipos de ambulância: básica e avançada. Estas últimas são UTIs móveis, com médicos e enfermeiros, e são as que deverão ser encaminhadas em situações de PCR. ${ }^{19}$

O fator definitivo na redução da taxa de mortalidade em uma PCR no ambiente pré-hospitalar é o intervalo de tempo entre a perda da consciência e a chegada do suporte avançado de vida pelo SAMU. Neste intervalo, é de suma importância o adequado acionamento do SAMU através do número 192, e o início das compressões torácicas (SBV). É imprescindível que a população tenha conhecimento sobre seu funcionamento e quando/como acioná-lo. Os resultados do presente estudo demonstram que apenas $16 \%$ dos jovens entrevistados não sabiam o número do SAMU (192) no pré-teste, sendo esse percentual inferior ao demonstrado em estudo anterior cuja amostragem com mais de 800 participantes nas cidades de Fortaleza, Salvador, São Paulo e Ribeirão Preto observou que somente $34,6 \%$ listaram corretamente "192" ou "193" como 
os números de telefone de emergência no Brasil, expondo assim, um déficit que atrasa e aumenta a mortalidade em casos de urgência. ${ }^{20}$

Outro aspecto que pode interferir no tempo de chegada do atendimento médico é a veracidade das informações após a ligação para o número 192, que realizada de forma completa e eficiente, reduz o tempo entre o envio da ambulância e o início da intervenção, garantindo o aumento da possibilidade de sobrevida em situações de PCR. ${ }^{21}$ No Brasil, a população ainda não tem consciência da importância desse serviço e da adequada comunicação, haja visto que a dinâmica de acionamento ainda é bastante prejudicada devido a "trotes". Segundo levantamento do Ministério da Saúde em 2008, 40\% de todas as ligações eram trotes. ${ }^{22}$ A escola é um importante celeiro para modificação do cenário social, visto que é neste

\section{REFERÊNCIAS}

1. Fernandes JM, Auto BS, Lima JE, Rivera IR, Mendonça MA. Teaching basic life support to students of public and private high schools. Arq Bras Cardiol. 2014;102(6):593-601.

2. Neumar RW, Shuster M, Callaway CW, Gent LM, Atkins DL, Bhanji F, et al. Part 1: Executive summary: 2015 American Heart Association Guidelines Update for Cardiopulmonary Resuscitation and Emergency Cardiovascular Care. Circulation. 2015;132(Suppl 2):315-67.

3. Fernandes FS, Tanaa OU. Processo de priorização de ocorrências no Serviço de Atendimento Móvel de Urgência. Rev Baiana Enferm. 2018;32:e24463.

4. Machado CV, O’Dwyer G. Serviço de Atendimento Móvel de Urgência: análise da política brasileira. Rev Saude Publica. 2011;45:519-28.

5. Duart SJ, Pena SB, Mendez RD, Candido MC. Acidente motociclístico: caracterização das vitimas socorridas pelo Serviço de Atendimento Móvel de Urgência (SAMU). Rev Bras Ciênc Saúde. 2014;18(1):3-10.

6. Cruz MC, Ferreira AS, Borges MT, Simonato LE . Conhecimentos sobre o Serviço de Atendimento Móvel de Urgência (SAMU) da população de Três Municípios com realidades distintas. Arch Health Invest . 2017;6(6):269-74.

7. Fernandes CR, Pinheiro JD, Costa JV, Costa PL, Melo-Filho AA. Conhecimento de estudantes de medicina sobre o funcionamento do Serviço de Atendimento Móvel de Urgência (SAMU). Rev Bras Educ Med 2014;38(2):253-60.

8. Dixe MA, Gomes JC. Knowledge of the Portuguese population on basic life support and availability to attend training. Rev Esc Enferm USP. 2015;49(4):640-9.

9. Castillo J, Gallart A, Rodríguez E, Castillo J, Gomar C. Basic life support and external defibrillation competences after instruction and at 6 months comparing face-to-face and blended training. Randomised trial. Nurse Educ Today. 2018;65:232-8.

10. Scaramuzzo LA, Wong Y, Voitle KL, Gordils-Perez J. Cardiopulmonary arrest in the outpatient setting: enhancing patient ambiente que se adquire parte dos princípios éticos e morais que permeiam a sociedade. Desse modo, há iniciativas que atuam nas escolas visando conscientizar tal público acerca dos prejuízos do trote, ${ }^{23}$ interferindo na dinâmica da cadeia de sobrevivência.

Conclui-se que houve significativa aquisição de conhecimentos teóricos por estudantes de ensino médio acerca da cadeia de sobrevivência, no que diz respeito ao reconhecimento de PCR, acionamento adequado do atendimento avançado préhospitalar, e suporte básico de vida, após intervenção teóricoprática por estudantes de medicina de uma Liga Acadêmica. Inferindo que estas ações de extensão promovidas por Universidades poderiam ser mais disseminadas em nosso país a fim de educar a população, contribuindo para a diminuição da mortalidade em casos de PCR em ambiente extra-hospitalar.

safety through rapid response algorithms and simulation teaching. Clin J Oncol Nurs. 2014;18(1):61-4.

11. Meissner TM, Kloppe C, Hanefeld C. Basic life support skills of high school students before and after cardiopulmonary resuscitation training: a longitudinal investigation. Scand J Trauma Resusc Emerg Med. 2012;20(1):31.

12. Jentzer JC, Chonde MD, Dezfulian C. Myocardial dysfunction and shock after cardiac arrest. BioMed Res. 2015;2015:14.

13. Pergola AM, Muglia IE. O leigo e o suporte básico de vida. Rev Esc Enferm USP. 2009;43(2):335-42.

14. Alves PP, Ferreira MA, Soares AW. Ressuscitação cardiopulmonar na escola: uma ação da Liga Acadêmica de Emergências Clínicas do Amazonas (LAEC-AM). Extensão em Revista. 2017;1(1):95-100.

15. Connolly M , Connolly D, McCluskey DR. The 'ABC for life' programme - teaching basic life support in schools. Resuscitation. 2007;72(2):270-9.

16. Ribeiro LG, Germano R, Menezes PL, Schmidt A, Pazin-Filho A. Medical students teaching cardiopulmonary resuscitation to middle school Brazilian students. Arq Bras Cardiol. 2013;101(4):328-35.

17. Corrado G, Rovelli E, Beretta S, Santarone M, Ferrari G. Cardiopulmonary resuscitation training in high-school adolescents by distributing personal manikins. The Como-Cuore experience in the area of Como, Italy. J Cardiovasc Med ( Hagerstown). 2011;12(4):249-54.

18. Machado CV, Ferreira FG, O’Dwyer G. Serviço de Atendimento Móvel de Urgência: análise da política brasileira..Rev Saúde Pública. 2011;45:519-28.

19. Scarpelini S. A organização do atendimento às urgências e trauma. Medicina (Ribeirão Preto). 2007;40(3):315-20.

20. Pontes-Neto OM, Silva GS, Feitosa MR, Figueiredo NL, Fiorot JA Júnior, Rocha TN, et al. Stroke awareness in Brazil: alarming results in a community-based study. Stroke. 2008;39(2):292-6.

21. Berdowski J, Zwinderman AH, Tijssen JG, Koster RW. 
Importance of the first link: description and recognition of an out-of-hospital cardiac arrest in an emergency call. Circulation. 2009;119:2096-2102.

22. Paiva RB. Percepção do ambiente externo e dos perigos do Serviço de Atendimento Móvel de Urgência (SAMU) a partir do enfoque dos sistemas sociotécnicos [dissertação]. Porto Alegre: Universidade Federal do Rio Grande do Sul; 2010.
23. Pereira AT, Santos EP, Sousa PS, Santos RC. Projeto de extensão "SAMU nas escolas"- uma estratégia pedagógica para redução dos trotes em Senhor do Bonfim, Bahia. Cidadania em Ação: Revista de Extensão e Cultura. 2018;30(2):144-55.

\section{Como citar:}

Nunes LM, Frota MK, Fernandes MA, Almeida TP, Sousa TM, Fernandes CR. Avaliação de conhecimentos de estudantes do ensino médio acerca da cadeia de sobrevivência em suporte básico de vida antes e após treinamento teórico-prático. Rev Med UFC. 2021;61(1):1-7. 